Article

\title{
Using E-Learning to Deliver In-Service Teacher Training in the Vocational Education Sector: Perception and Acceptance in Poland, Italy and Germany
}

\author{
Christian Hofmeister ${ }^{1}$ and Matthias Pilz ${ }^{2, *(D)}$ \\ 1 Vocational Education and Training, German Economic Institute, 50668 Cologne, Germany; \\ hofmeister@iwkoeln.de \\ 2 Chair of Economics and Business Education, University of Cologne, 50931 Cologne, Germany \\ * Correspondence: matthias.pilz@uni-koeln.de
}

Received: 8 April 2020; Accepted: 9 July 2020; Published: 13 July 2020

check for updates

\begin{abstract}
For teachers in vocational education and training (VET), lifelong learning and related further training is important to meet the growing demands of the teaching profession. This paper analyses the perception of technology and e-learning of teachers in Poland, Italy and Germany. The innovative aspect of this study lies in its combination of general perceptions of online learning and technology on the one hand and findings in relation to a specific online Teacher Training Tool on the other hand. The aims of this study are to show the relevance of e-learning in teacher training and to measure the perception and acceptance of this form of further training by VET teachers. The results should provide support for the further design and development of online education formats for teachers. The evaluation was carried out using a quantitative cross-cutting study using a standardised questionnaire. The results of an online questionnaire show that the approach of online learning as a form of teacher training was met with great interest among VET teachers and that the perception of one's own benefit from such a training option was positive. The quality of the online learning units is decisive for the acceptance of e-learning opportunities. One limitation of this study is that the diverse country-specific cultural aspects and systems of teacher training could only be taken into account to a limited extent. This paper enables international comparative research on teacher training to be integrated using e-learning formats.
\end{abstract}

Keywords: online learning; in-service VET teacher training; acceptance; Teacher Training Tool; teacher perception

\section{Introduction}

Over recent years, digitalisation has become an increasingly important focus of both European corporate policy [1-4] and vocational education and training [5,6]. The demands made of employees in their work—and, therefore, also of vocational training-are evolving continuously as a result of digital processes [4]. Meanwhile, modern learning media and formats can be shown to have a motivating effect on students [7] (p. 7); [8] (p. 3); [9] (pp. 18-20). There are also some approaches on how digital learning or e-learning can be implemented in the school context (see, for example, $[10,11])$. The literature and research findings in this area tend to focus mainly on teaching or on how students learn using digital media and learning formats [12-15]. Online learning is, therefore, a key theme in teaching and learning.

To enable teachers to take a targeted approach toward identifying students' needs, responding to those needs and guiding students in the use of digital learning environments, they must have an 
adequately broad personal experience in this area [16]. A literature review indicates that vocational education and training (VET) research so far incorporates only a few-inadequate-approaches to exploring how vocational school teachers make use of digital media and online learning as tools for their own learning. These include studies from the teachers' perspective of how online learning impacts on them and of their attitudes to it. This gap in the research is surprising, given that teachers are now able not only to participate in face-to-face in-service training but also to make use of opportunities for e-learning to reflect on their own expertise and develop their skills, and that e-learning is advantageous to many, given the constraints on their time. The potential of virtual training resources has been clearly documented (see, for example, [17-20]): teachers can make use of learning opportunities when and where they choose to meet their training needs. Moreover, virtual training provision is accessible and diverse; materials can be accessed more easily, quickly and comprehensively; and because online training provision is so diverse, individual teachers remain in control of the time they spend and the intensity of their learning. This also means that teachers are able to set their own learning priorities. To make full use of the potential of online learning for in-service teacher training, however, participants need good basic digital skills (the ability to use a computer or tablet) and a positive attitude to digital learning media and formats [16]. The current discourse around in-service teacher training in Europe demonstrates broad consensus that, following their initial training, teachers need to top up their skills on an ongoing basis and as part of their everyday activities [21]. European countries take a wide range of approaches to in-service training for teachers, which is often regulated by law. In some countries, teachers even have a legal entitlement to such training in order to ensure that schools offer quality education [21] (p. 6). However, it is usually the responsibility of the teachers themselves to establish what training they need in order to maintain their ability to meet the growing demands of the teaching profession. In-service training for teachers often takes place outside regular working hours because of participants' teaching commitments during the school day [22] (pp. 46-47); [23]. Flexible training that can be tailored to the needs of individual teachers (including through online learning), therefore, offers a convenient way of enabling teachers in Europe to engage in lifelong learning and continuing professional development.

The research focus of this article is, therefore, to present and discuss the perception and acceptance of online learning, respectively, and digital learning formats of vocational school teachers in three countries in Europe. Within this article, the possibility and relevance of e-learning as a further education format for teachers should be discussed. In addition, important aspects of the quality and acceptance of an online Teacher Training Tool should be proofed.

The results can support the further design and development of online further education formats for teachers. As a consequence, the focus is on online learning as an instrument for further education of teachers and not as a method for their own teaching.

Vocational school teachers from Germany, Italy and Poland were asked about their attitudes to computer technology and e-learning in general and specifically to online learning as a tool for in-service teacher training. The inclusion of the survey data enables a general assessment of vocational school teachers regarding the use of computer-based technology for everyday work and thus also as a form of further training. Further, important quality and acceptance criteria can be checked using a specific online learning tool.

These countries were selected because they have very diverse vocational training systems and arrangements for the initial and continuing training of vocational school teachers. Due to the different academic background (in terms of content area and pedagogy), the duration, the practical and theoretical content, etc., findings can be generalised beyond the sample [21].

\section{Current Status of Research}

Over recent years, a number of continuing training concepts have emerged that bring together learning and digitalisation. As already mentioned, the focus of this article is on e-learning. There are a variety of terms used to describe online-based learning. These include "web-based learning, 
e-learning, Internet-based learning, online learning, distance learning, distance education, distributed learning, computer-mediated learning" [24] (p. 99), which can be used synonymously. In comparison to traditional teaching and learning, e-learning is a form of learning based on use of an electronic device and digital media and "a form of distance education where technology mediates the learning process, teaching is delivered completely using the internet, and students and instructors are not required to be available at the same time and place" [24] (p. 100). As noted above, e-learning can boost the accessibility of education and training: "e-learning technology opens possibilities for new ways of engagement and invites innovative pedagogies" [25]. E-learning "[ ... ] facilitates transmitting the digitized knowledge from the online sources to the final user devices, like a laptop, desktop and handheld devices" [26] (p. 511). E-learning also offers teachers involved in a range of teaching activities the opportunity to appropriate new content when and where they choose without having to attend face-to-face training formats. With regard to the investigation and the definitions found across the literature, we distinguish between two specific terms associated with e-learning: distance learning and online learning. Distance learning is defined as a learning process in which the learners solve tasks assigned online in self-study and send them back online to the lecturers. Distance learning generally includes the presentation of an online lesson accompanied by the lecturer. The lecturer enriches this with digital didactic methods and interactions. Distance learning usually takes place online with concurrent participation by the learners and the lecturer [27,28]. In contrast to distance learning, online learning can be understood as independent learning with the help of online learning resources. Online learning is a form of e-learning in which the learning content is available to the learner online and can usually be completed independently and at any time, regardless of the time. The teaching-learning process is supported by the use of information and communication technologies (ICT). In our study, we focus on the format of online learning.

In the research literature, the use of e-learning by teachers has often been investigated in connection with day to day school activities, particularly teaching. An Estonian study [29] reports that approximately $97 \%$ of all students in a VET teacher program aged between 15 and 19 have access to information and communication technology (ICT) and to the internet, and this is increasing the pressure on both schools and individual teachers to integrate the use of ICT into their teaching practice (see also [30]). A similar result exists in a broader European context. A total of $95 \%$ of young people between the ages of 16 and 19 use ICT every day [31].

Earlier sources show that teachers' attitudes to e-learning and their knowledge and skills in this area are crucial to their acceptance of and future use of ICT [32,33]. More recent studies have generated similar findings: Loogma et al. [29] argue that vocational school teachers' digital skills and competencies are crucial to their ability to make long-term use of online learning. In our view, they may also serve as an indicator of those teachers' own use of ICT, in particular for online learning. Other authors argue that teachers may lack the skills to use online learning successfully and in a targeted way [34] (p. 1); [35] (p. 22). Ernest et al. [34] describe how a continuing training programme for teachers was designed both to raise their awareness of online learning models as a form of collaborative learning and to establish their needs for continuing training in this area. Their study also illustrates how teachers perceive online learning approaches. The data show that the majority of teachers surveyed were open to the idea of taking part in an in-service training programme of this kind. Jung [36] views current technologies as essential tools for teaching and learning because they open up new opportunities for teachers. However, they also impose higher demands on teachers who use new technology in their classrooms [37] or for their continuing professional development. To meet these challenges, it is essential that teachers participate in ongoing training to keep their own knowledge and skills up to date [38]. ICT presents a way to offer teachers more flexible and more effective opportunities for lifelong learning and is, therefore, suitable for in-service training and continuing professional development [36] (p. 94). Teachers can undergo training to help them use ICT in their teaching or make use of it for their own training. 
This approach is already being used in international in-service training for teachers and, in particular, includes e-learning approaches that support in-service training and network teachers. The international training landscape also already offers a number of internet-based training services, including the UK's Virtual Teacher Centre, Korea EduNet, the US Teachers Network, SchoolNet SA, and the European Schoolnet. This approach enables teachers to directly access teaching and learning materials for self-study and support with a range of pedagogical issues. Jung [36] regards the online learning approach as offering good support for teachers' continuing professional development. However, the issues of how teachers actually perceive online learning as an in-service training format and their attitudes to this form of ICT remain unexplored. One study in particular demonstrates that teachers' confidence in the use of ICT generally has an influence on their willingness to make use of online learning [25] (p. 239). Because there is so little international literature on perceptions of online learning as a tool for in-service training for vocational school teachers, this article helps to fill the research gap.

\section{Theoretical Framework and Design of This Study}

\subsection{Acceptance and Attitude to Online Learning}

The focus of our analysis is teachers' attitudes toward online learning and their general acceptance of this form of in-service training. This study, therefore, fits into the area of 'acceptance research' in relation to e-learning $[39,40]$. In particular, we sought to explore how vocational school teachers perceive online learning as a tool for personal in-service training. Acceptance research frequently makes a distinction between attitudinal acceptance (general acceptance of virtual media and online learning, for example) and behavioural acceptance, which is the actual practical use of online tools (see [41] (pp. 214-215)). Goodhue [40] focuses on attitudinal aspects, while Davis [39] focuses on behavioural aspects. Research into these aspects shows that successful use of or participation in e-learning is likely to depend largely on a positive attitude on the part of the learner toward such strategies. A positive attitude is characterised by a perception that such online learning tools are easy to use and are of benefit [25] (p. 13). Attitudinal acceptance on the part of a learner underpins his or her behavioural acceptance. To demonstrate how an online learning tool is perceived in the context of in-service teacher training, the discussion below relates solely to attitudinal acceptance; this study did not observe actual long-term use (behavioural acceptance).

Attitudinal acceptance comprises a cognitive component and an affective component [41] (p. 215). The affective component includes the emotional aspect of motivation, which operates at the level of the learner's feelings: is a learner rejecting online learning as a tool for in-service training, for example, or does he or she view it as an attractive and interesting tool? By contrast, the cognitive component involves a (rational) cost-benefit analysis that reflects the individual's personal context. In our case, the cognitive component relates not to the financial cost of online learning but to the effort required of learners (here, vocational teachers) and is based on their assessment of the advantages and disadvantages of e-learning, which underpins their attitude to this training format.

\subsection{Perception of an Online Training Tool for Vocational School Teachers}

As noted above, findings relating to teachers' attitudes to e-learning are currently very general, and the issue of how vocational school teachers evaluate the use of an online in-service training format has received little attention. The innovative aspect of this study is that it links the general perception of vocational school teachers to online learning and technology with a set of findings relating to a specific online training tool. We recorded not only teachers' assessment and evaluation of online learning in general, but also their perception and evaluation of one specific online learning tool used for in-service training.

This online tool covers four training areas on the topic of teaching personal and social competencies, which teachers can work through individually in line with their needs. An overview page provides 
additional information on the design of the tool, its objectives and its approach. This is particularly important for vocational school teachers with poor technological skills, as it enables them to make full use of the tool.

The online tool also had to include a mix of text, videos and images to make it more attractive. Time was also an important consideration at the development stage (see, for example, [42] (p. 148)); it was important that the tool did not make excessive demands of users' time. User-friendly navigation was a further priority, but the time factor was also relevant to the design of the content. The tool was intended to provide explanations, content and methods in relation to training content as rapidly as possible. To sum up, the exercises and instructions for vocational school teachers needed to be manageable in terms of time and capable of being accessed and worked on at any time and from anywhere.

In compiling this online tool, we were also keen to consider further demands: if the tool was to be used across Europe, for example, it had to be made available in a range of languages, including English. The transnational use of the learning content requires the different conditions of the vocational school teachers to be taken into account. This was considered in all different language versions of the training tool.

In evaluating an online tool as an in-service training format, we also wanted to gauge the perceived quality of such a tool, so quality was a further dimension we wished to measure. The concept of 'quality' is a highly complex one and, like acceptance, is influenced by a range of factors. The quality of the training tool is not only crucial to teachers' motivation to complete the training but must also be tailored to the teachers themselves: "A key feature of effective in-service and continuing training is that it focuses on curricula and the specialised content that teachers actually have to teach" [43] (p. 352, authors' own translation). Here, Lipowsky [43] is referring to the importance of appropriate specialist content and its centrality to the success of any training measure. To formulate appropriate quality indicators, we considered the demands and needs of teachers in relation to a Teacher Training Tool as well as integrating the findings of specific research into the quality of e-learning environments $[19,26,44,45]$. Multimedia content supports a range of learner types. The literature consistently argues that the combination of visual and textual content generally supports learning more effectively than purely textual content [46] (p. 175). Usability (user-friendliness) is a further qualitative component of any e-learning module: "In fact, usability evaluation plays a vital role within the overall user interface design process [ ... ]" [47] (p. 437). Perceived usability also underpins Davis's [39] technology acceptance model. Our evaluation focused on two aspects: teachers' general attitudes to technology and e-learning, and their attitudes to a specific online Teacher Training Tool. This latter aspect was investigated in greater detail using two dimensions, 'acceptance' and 'quality'. 'Quality' is a multidimensional concept, so it was measured by means of five indicators. In our understanding, the quality dimension has a positive or negative impact on the acceptance dimension (see Figure 1). Our aim in focusing on these two dimensions was to identify the extent to which teachers accept and rate online learning as a form of in-service training. The evaluation was carried out by teachers in vocational schools in Germany, Italy and Poland. The selection of the countries included different vocational training systems as well as different teacher training concepts within the framework of a 'most different design' (for further information on the general differences between the vocational education systems and the teachers training in Germany, Italy and Poland, see [48-50]. 


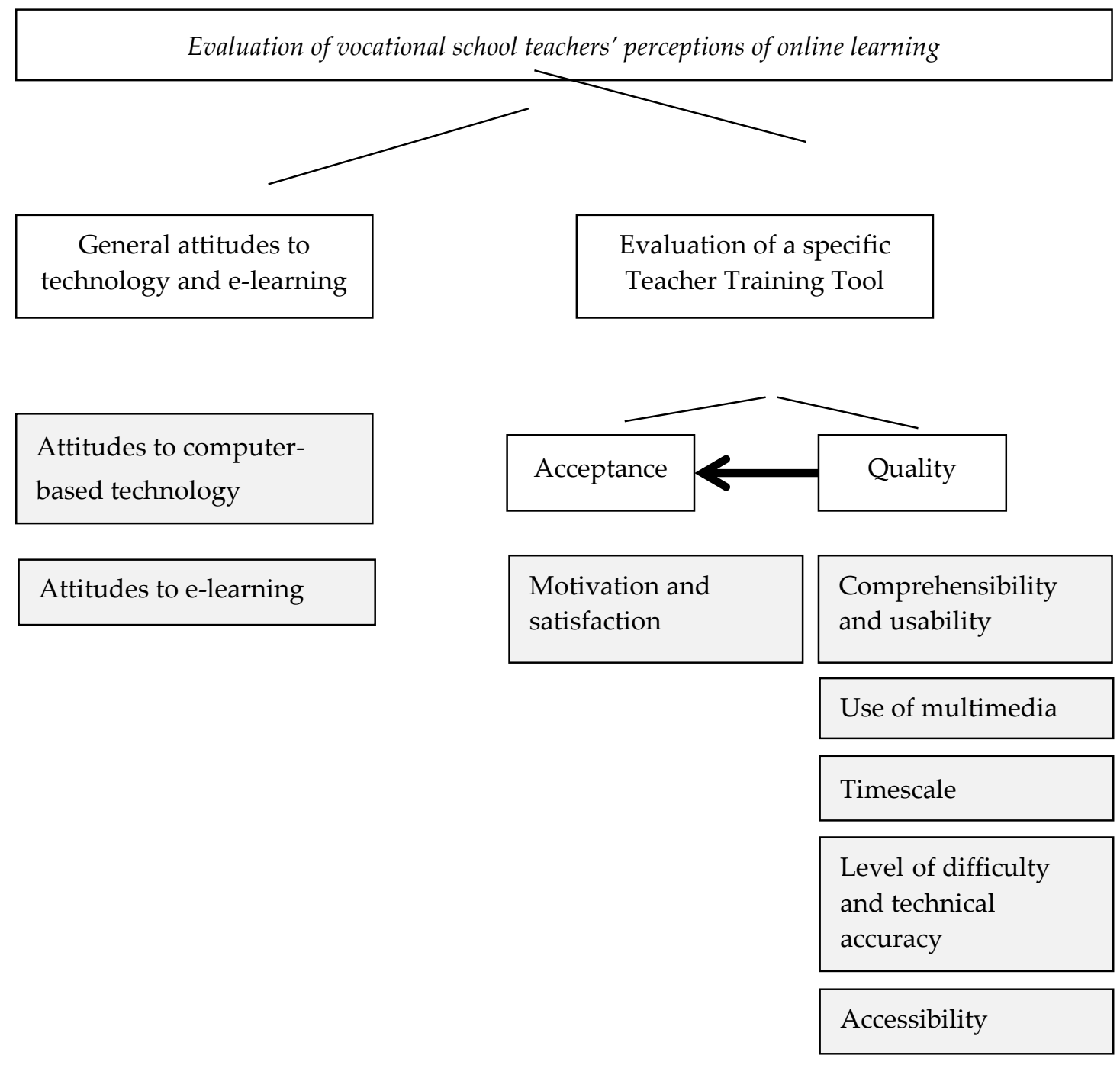

Figure 1. Overview of variables and indicators; authors' own compilation.

\section{Methodology and Implementation}

The vocational school teachers evaluated their attitudes towards a specific Teacher Training Tool immediately after completing the online training. Our study was a cross-cutting study [51,52], within a research and pilot implementation project. Given the linguistic and cultural differences between teachers, we chose a quantitative survey using a standardised questionnaire. We used back-translation $[53,54]$ to overcome the language barrier, meaning that we were able to generate a (virtually) identical formulation for the questionnaire across the three languages. Teachers in the participating schools were not required by their principals to take part, so participation in the evaluation was voluntary and they accessed the questionnaire in the appropriate language via a web-based evaluation tool. Approximately 170 teachers in Germany, Italy and Poland were contacted by email and invited to participate, with a response rate of $44 \%$ (74 teachers). The vocational school teachers were selected and contacted locally in the respective countries. For budgetary reasons, the selection could not follow a random approach, but was dependent on the contacts of the national research partners with the local vocational schools. When making the selection, care was taken to ensure that teachers were focused in commercial training professions [55]. The response rate can be linked to the fact that the survey was voluntary. We also discussed the findings in detail with country experts who were involved in the project. 
As another step to ensuring quality, the questionnaire was subject to pre-testing for validity and usability [56]. A country-specific proof of the questionnaire was carried out by the vocational school teachers involved in the project in Germany, Italy and Poland. An additional five vocational school teachers from outside of the project team were included in the pre-testing of the questionnaire. Pre-testing questionnaires were administered anonymously so that the learners or experimental subjects-in this case, the teachers-were not inhibited and could be as honest as possible in their responses. The questions were formulated in such a way that the participants were able to understand them through a single reading, maintaining their motivation to complete the questionnaire. The questionnaire itself was divided into three parts: demographic data, responses on e-learning in general, and responses on the specific Teacher Training Tool. The main items were assessed using a 4-point scale $[57,58]$, in which teachers rated comments on a scale from very positive (4: 'Strongly Agree') to very negative (1: 'Strongly Disagree'). A 4-point scale was chosen in order to get a response tendency from the teachers. There is no "neutral" option with this scale form. This procedure is suitable for capturing opinions (e.g., regarding a product). The items were derived on the basis of variables from acceptance research (see section on theory).

Figure 1 gives an overview of both dimensions and the derived indicators that were of significance to our research. The data were evaluated on the basis of mean value calculations and checked with the help of t-test for significant differences between personal characteristics, for example age, gender and country. OLS regression was also performed. For the regression, the individual items were clustered according to indicators (see also Figure 1). Between 3 and 10 items were received in each indicator. The mean value of all items was calculated for each indicator and used for the regression.

\section{Findings}

A total of 74 vocational school teachers from Germany, Italy and Poland took part in this study (Germany: $\mathrm{n} 27$, Italy: $\mathrm{n}$ 16, Poland: $\mathrm{n}$ 31). The findings reported below are the aggregated findings across the three countries, with country-specific findings explored in the 'Discussion' section. Figure 2 gives a demographic overview of the sample of teachers taking part in the evaluation.

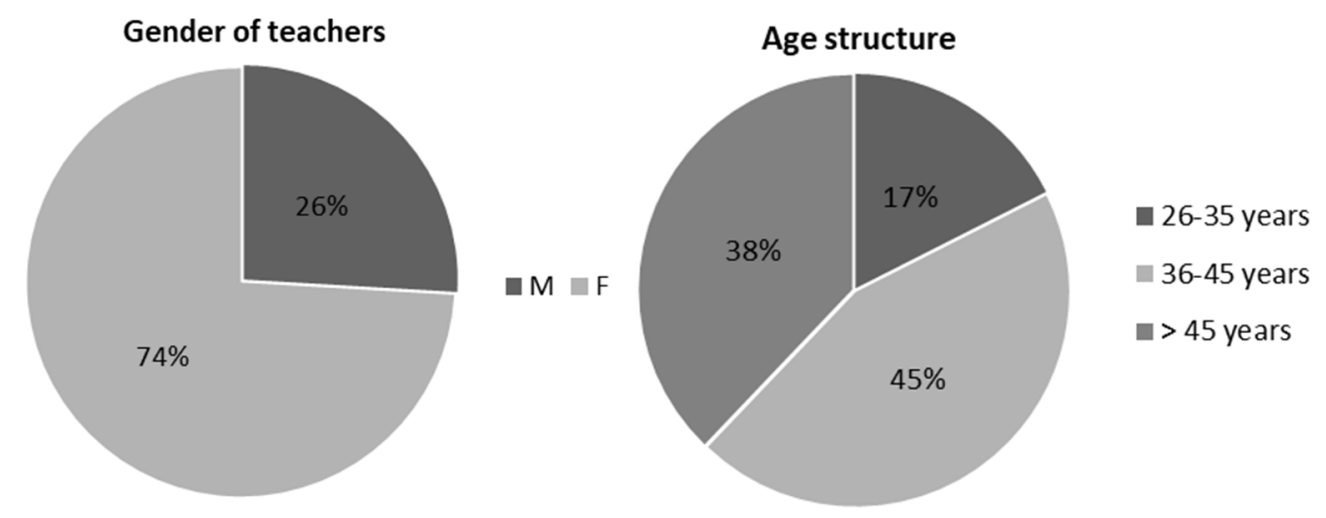

Figure 2. Demographic data.

The first point of interest is the prior knowledge reported by the teachers. Figure 3 shows what approaches the teachers had previously taken to broadening their skills and knowledge.

The findings show clearly that less than one-third of the teachers surveyed had previously used online learning as a tool for their own in-service training, preferring formal training formats and self-study. 


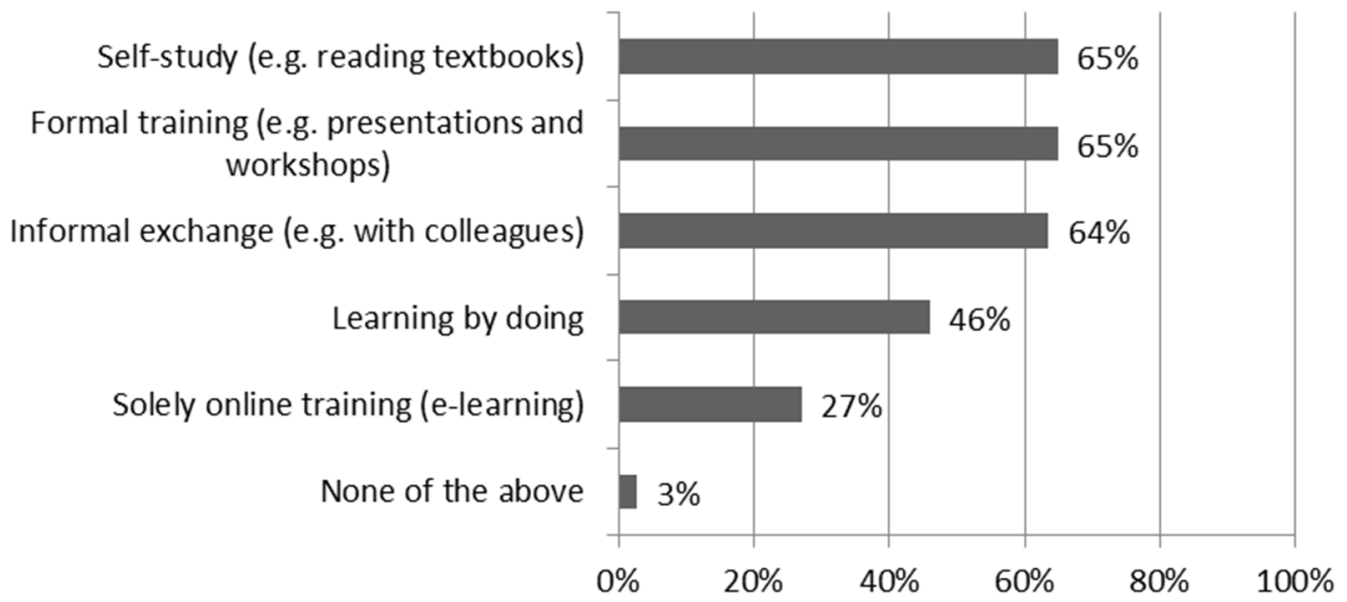

Figure 3. Teachers' prior experience of a range of learning environments.

\subsection{General Attitudes to Computer Technology and E-Learning}

The 'General attitude to technology and e-learning' variable comprises two indicators. We began by assessing teachers' general experience, starting with a closer consideration of 'Attitudes towards computer-based technology' as an indicator for this variable. It should be noted that the findings show that all the teachers in this study had a desktop computer or mobile device. Aggregating the findings from all the questions on general attitude to technology produced a high value (M 3.43; SD 0.83), indicating that, in general, teachers are open to working with a computer (including all individual desktop and mobile devices; see Figure 4).

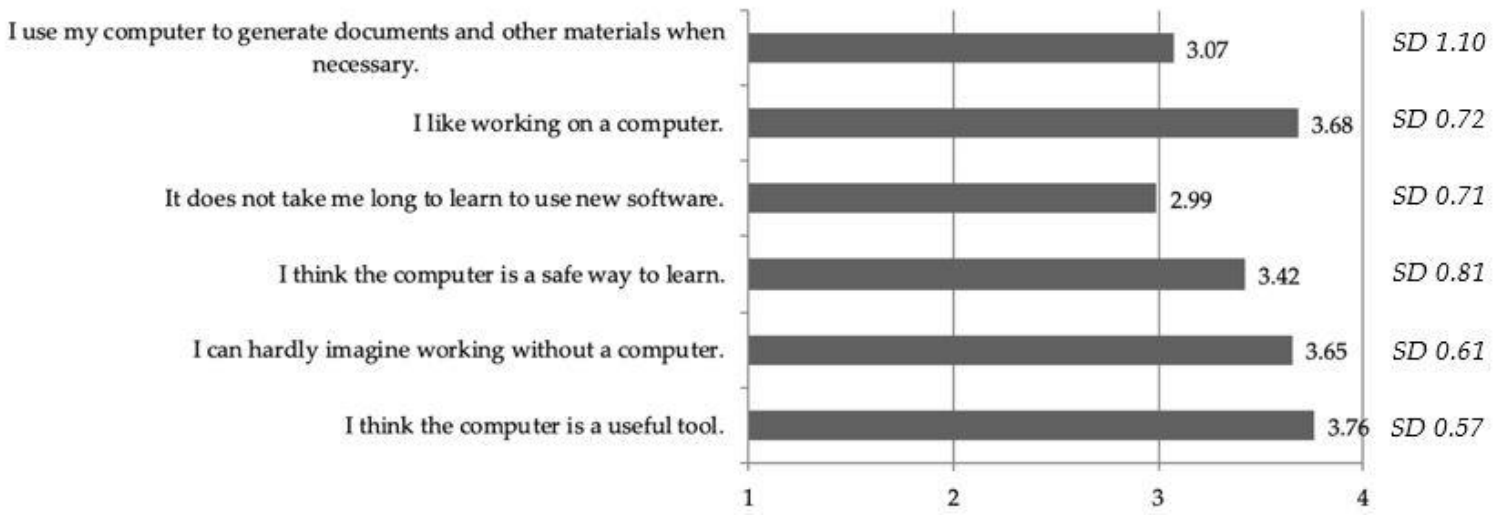

Figure 4. Attitudes to computer-based technology. $1=$ Strongly Disagree; $2=$ Slightly Disagree; $3=$ Slightly Agree; 4 = Strongly Agree.

A breakdown by gender and by age showed no significant differences on these variables. The teachers perceive using a computer in their day to day work as helpful and important (M 3.76; SD 0.57). In practice, computers support teachers in their work, so most teachers are capable of coping with new software without additional help (M 2.99; SD 0.71).

There was, however, a less positive response on the second indicator, 'Attitudes to e-learning'. While attitudes to computer-based technology were very positive, aggregating the findings for the second indicator produced a major variation (M 3.0; SD 0.82) (see Figure 5). This may be attributable to the fact that vocational school teachers currently have insufficient access to e-learning provision or may previously not have explored this type of in-service training. 


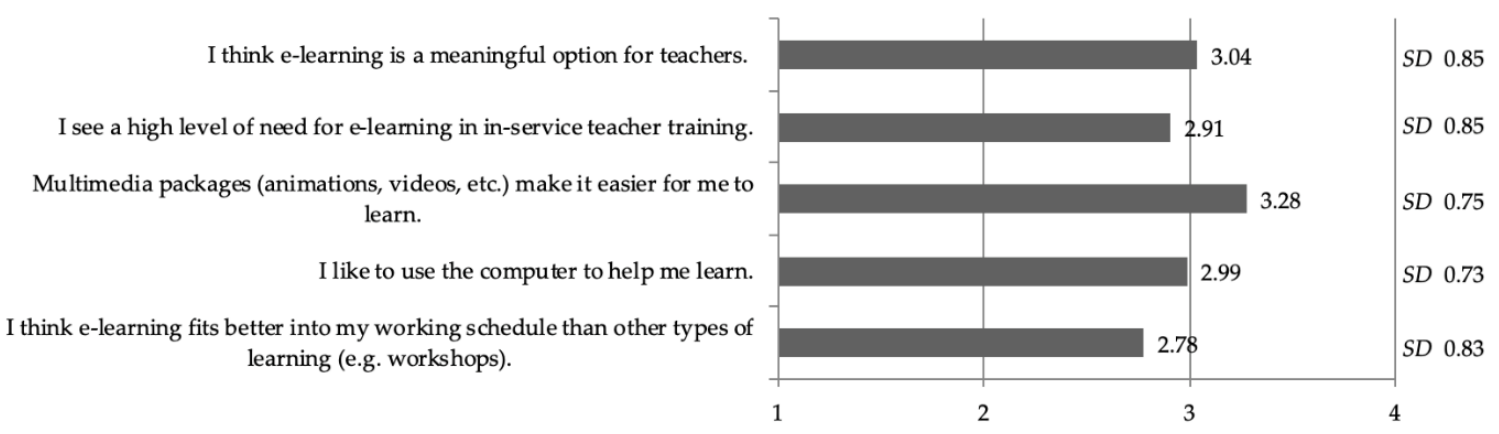

Figure 5. Attitudes to e-learning. 1 = Strongly Disagree; 2 = Slightly Disagree; $3=$ Slightly Agree; $4=$ Strongly Agree.

Nonetheless, the findings show that multimedia content makes it easier for teachers to learn in an online environment (M 3.28; SD 0.75). Questions on this aspect revealed a significant difference between teachers of differing age groups. The 36-45 age group (M 3.21) reported a significantly easier experience of learning with multimedia content $(p<0.05)$ than the $26-35$ age group (M 2.92). It should be noted, however, that by comparison with other forms of in-service training, and against expectations (see Section 1), e-learning was not so easy to integrate into teachers' working schedules (M 2.78; SD 0.83). The design of this study did not enable us to identify the reasons for this. Moreover, while there was no significant gender difference on the 'Attitudes to e-learning' indicator, there was a highly significant gender difference in terms of use of e-learning: men make significantly more frequent use $(p<0.001)$ of e-learning tools than women (M 2.68 and M 2.03, respectively). These findings were recorded using a 5-point scale: $(1=$ never, $2=$ several times a year, $3=$ several times a month, $4=$ several times a week, and $5=$ every day).

Teachers articulate a fundamental need for computer-based technology and online learning. The 'General attitudes to computer technology and e-learning' variable produced a value of M 3.23 and SD 0.85 on both indicators.

\subsection{Views of a Specific Teacher Training Tool}

'Acceptance' was one of the dimensions of evaluation of a specific Teacher Training Tool. Acceptance relates to vocational school teachers' motivation and satisfaction, factors that contribute to their likelihood of completing a course of online training of this kind (see, for example, $[59,60]$ ). However, this dimension alone sheds no light on the teachers' specific assessment of the quality of the online tool, so this aspect was analysed by means of a range of indicators. The selected indicators are listed in Figure 1.

\subsubsection{Quality}

Aggregating the findings in relation to all five quality indicators produced a good result (M 3.25; SD 0.72). Teachers in Germany, Italy and Poland were all satisfied with the quality of the Teacher Training Tool available in their own language (see Figure 6). Comparison of individual indicators (see Figure 7) showed that the timescale was very important to them (M 3.41; SD 0.65); this related to having adequate time to use the Teacher Training Tool and the opportunity to select training content that met their needs. Teachers also appreciated the possibility to stop and resume the training at any point. For example, areas of training could be completed piecemeal during their leisure time or while travelling to school on public transport. 


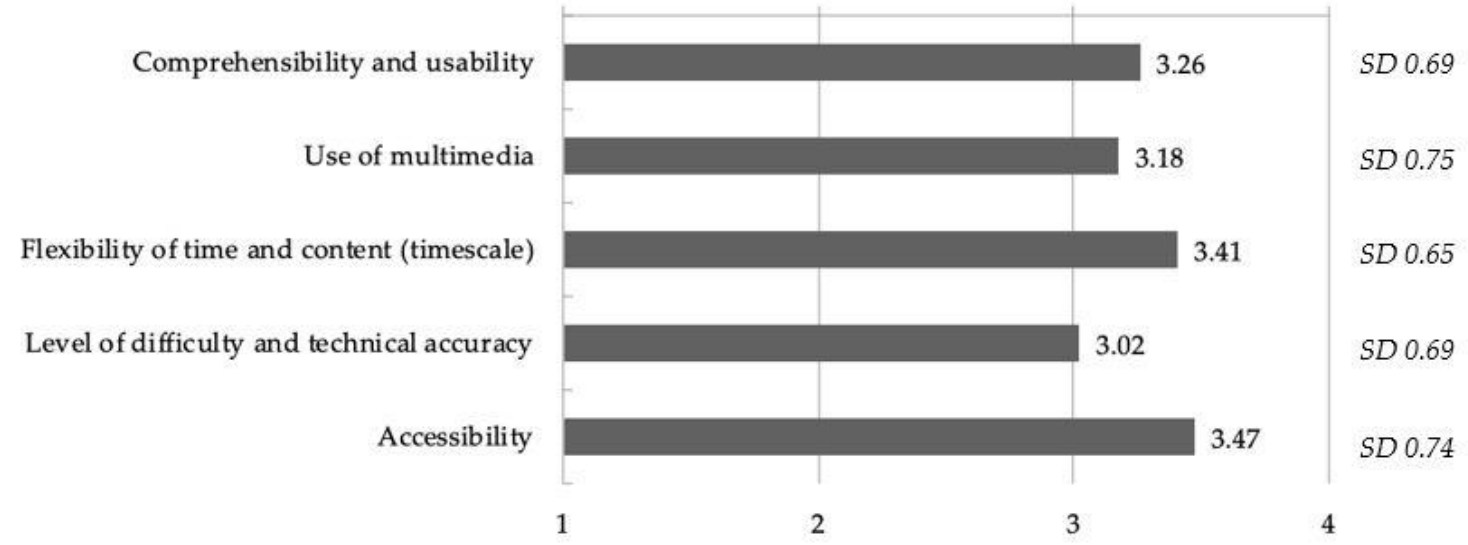

Figure 6. Quality indicators of an online training tool. $1=$ Strongly Disagree; $2=$ Slightly Disagree; $3=$ Slightly Agree; 4 = Strongly Agree.

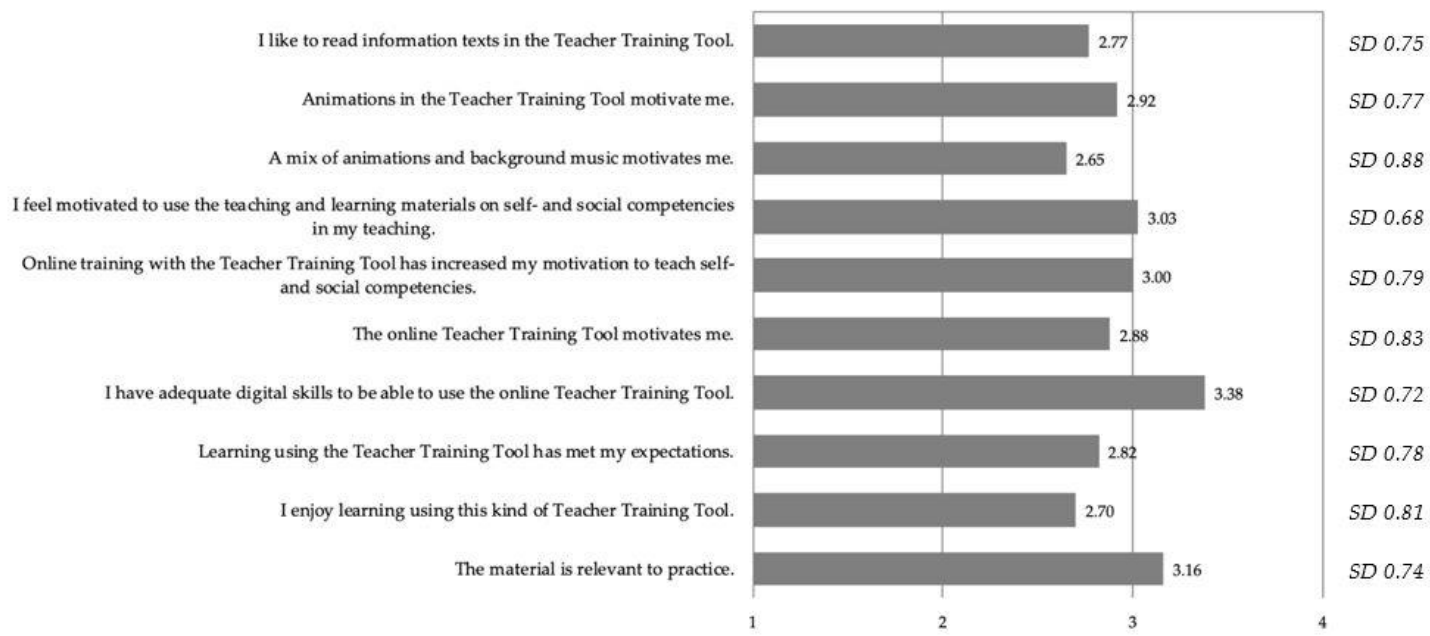

Figure 7. Motivation and satisfaction 1 = Strongly Disagree; 2 = Slightly Disagree; 3 = Slightly Agree; 4 $=$ Strongly Agree.

Closer analysis of the 'Accessibility' indicator (M 3.47; SD 0.74) revealed that not all teachers were able to use the full scope of the Teacher Training Tool because of their digital skills, although this was not significantly affected by age or gender. To avoid such problems in the longer term, we introduced some technical guidance following the evaluation. This was intended to help users with lower levels of technological skills.

Multimedia content was appropriate and easily understandable for most of the teachers (M 3.18; SD 0.75), with only occasional differences between different types of learners. Some of those surveyed found, for example, that it was easier to learn when videos included background music, while others found the music intrusive. The 'Comprehensibility and usability' indicator (M 3.26; SD 0.69) reflected the perception that the tool had been developed in a structured, meaningful and straightforward way.

Finally, the accuracy of content and the level of difficulty of the training content were key quality aspects that contributed to effective learning. Of additional importance here was teachers' perceptions of whether the training content was pedagogically appropriate to the target group and, therefore, easier to access. The aggregated value of the training content (M 3.02; SD 0.69) was the lowest of all the quality indicators. This is unsurprising, given that the teachers' (individual) needs varied across individual countries, although from a qualitative perspective, care was taken from the outset to reflect cultural factors in the specific language versions of the Teacher Training Tool. The low, but satisfactory, value may be attributable to the teachers' prior training and experience. 
Overall, the teachers accepted the quality of this specific online in-service training tool and rated the tool a success. The findings suggest that when an online in-service training tool is being designed for vocational school teachers, it needs to reflect their professional practice and day to day routines. There were no significant age or gender differences between teachers in their perceptions of quality.

Alongside 'quality', the dimension of 'acceptance' is particularly important. Acceptance includes teachers' motivation to use an online tool of this kind for in-service training and satisfaction with it (see Figure 7).

\subsubsection{Acceptance}

Aggregating the responses to all questions on motivation and satisfaction produced an average value of 'good' (M 2.91; SD 0.80). This can be attributed to differences in teachers' motivational perceptions. It was clear that teachers were more motivated to learn using a Teacher Training Tool that included animations and videos (M 2.92; SD 0.77) than with a purely text-based format (M 2.77; SD 0.75). This reflects the findings of existing studies of e-learning provision (see Sections 1 and 2). The predominant finding is that teachers feel motivated by the tool to tackle the content on self- and social competencies independently (M 3.00; SD 0.79). Teachers who have already tackled this area during their training or day to day teaching and, therefore, need less training may find this aspect motivates them less. Following the online training, a majority of teachers were motivated to use the training content (topics and teaching and learning materials) in their own teaching (M 3.03; SD 0.68). In relation to digital skills, there were no significant gender or age differences. The aggregated value here was M 3.38 (SD 0.72). Most of the teachers surveyed had adequate digital skills to take part in e-learning measures. What is striking is the lower value (M 2.70; SD 0.81) for the question as to whether the teachers had enjoyed learning using the Teacher Training Tool. We can only speculate on the reasons for this, as demographic factors played no role. One reason may be a general disinclination on the part of some teachers to undergo in-service training outside their working hours, or they may have had only limited need for training in the areas covered by the content of the tool in the case of others. By contrast, the relevance to practice in terms of motivation and satisfaction was rated positively (M 3.16; SD 0.74), with these factors rating significantly higher among women (M 3.31) than among men (M 2.74; $p<0.01)$.

An OLS regression was carried out for the dimensions "quality" and "acceptance". Acceptance acted as a dependent variable, and the various quality indicators served as independent variables. Significant coefficients were shown for the dimensions comprehensibility and usability, use of multimedia, timescale and difficulty and technical accuracy. There was no significance for the accessibility dimension, which showed little variance. This was not surprising and could be justified by the fact that the vocational school teachers had hardly any access problems to the Teacher Training Tool and, therefore, rated this indicator very positively with regard to the online tool. With an $R^{2}$ of 0.54 and an F-value of 20.15, the regression with the quality features has a high explanatory value for the variance in the acceptance of the Teacher Training Tool. A linear regression analysis with the dimensions quality and acceptance by gelation analysis revealed a correlation coefficient of $r=0.2907$, empirical evidence of a highly significant correlation between the two dimensions $(p<0.001)$. This shows how closely these two dimensions are linked and confirms that online further training must meet the highest quality criteria if they are to ensure the acceptance of teachers against online further training offers.

As learners, the teachers surveyed, therefore, rated the quality and acceptance of the online in-service training tool positively (M 3.16; SD 0.75), which—despite the sample size-can be regarded as evidence of a positive perception of e-learning as a tool for in-service training. The positive general perceptions of technology and e-learning were confirmed by use and evaluation of the specific Teacher Training Tool. As a result, there were only minor changes on the part of individual teachers in their perceptions of e-learning. Participants were slightly more likely after using the Teacher Training Tool to report that multimedia content made learning easier. There was positive change on the 
question of whether participants viewed e-learning as a meaningful format for in-service training (before using the tool, M 3.04; SD 0.85; after using the tool, M 3.14; SD 0.67). Following in-service training using the Teacher Training Tool, 64 of the 74 teachers said they would use e-learning again; the remaining 10 teachers said they would not. Approximately $80 \%$ of the teachers surveyed would recommend e-learning to their colleagues, helping to disseminate online in-service teacher training via an e-learning tool.

\section{Discussion}

Caution must be exercised in discussing the findings because the sample was small and does not reflect a representative overview of vocational school teachers' perceptions of online learning. Nonetheless, we would like to begin by discussing the attitudes of teachers to online in-service training. As the findings show, attitudes to computer technology are positive across all age groups. However, despite this general positive attitude to e-learning, many teachers do not believe it can easily be integrated into their daily working and school routine as a format for in-service training (see Figure 5). This study was unable to disaggregate the reasons for this, and further research is required in this area. As noted above, online training offers teachers a number of advantages by comparison with traditional in-service training (see, for example, [19]). We concluded that smaller training units on a particular topic within broader online training provision were particularly likely to meet teachers' needs. Evaluation of the Teacher Training Tool showed that the aggregated values for 'acceptance' and 'quality' and their indicators were positive across the board. The regression analysis, with the significant quality characteristics, has a high explanatory value for the variance in the acceptance of the Teacher Training Tool, with the result that teachers' perceptions of quality influenced their acceptance of online in-service training. This shows how closely interlinked these two parameters are and also confirms that e-learning measures for in-service training measures must meet the highest quality criteria if they are to secure the acceptance of the target group. There was a significant gender difference in relation to perception of the Teacher Training Tool, with women being significantly more likely than men to make use of the teaching and learning materials to supplement their own teaching $(p<0.01)$.

Views of online learning for teachers also differed from country to country. Despite the small size of the sample, we would like to highlight individual cross-country differences here. In line with common statistical procedures, the t-test is appropriate with a survey sample of $n>30$ [61]. We shall, therefore, present significant data solely relating to comparisons between Germany and Poland; from an Italian perspective, we shall be able solely to describe our impressions. By contrast with their German counterparts (M 2.93), Polish teachers (M 3.42) were significantly more satisfied with e-learning as a training format $(p<0.001)$. In this respect, the perceptions of Italian vocational school teachers were similar to those of German teachers. The major problem areas facing the staff teaching in vocational training institutions in Poland are the scarcity of resources for continuing and in-service training of teachers and inadequate functionality of the structures for methodological advice and continuing training in the vocational training sector [62] (pp. 7-8.). Moreover, most universities still show little interest in providing in-service training for vocational school teachers, which hugely restricts these teachers' scope for adding to their skills [63] (p. 271). This may also indicate that Polish teachers take a positive view of any free online training provision, which has so far been in short supply in the country. Country experts from Poland confirmed in an interview with us that Polish vocational school teachers generally have no access to electronic learning tools that they could use not only within school but also from home. An online learning tool of this kind is, therefore, is entirely new for teachers in Poland, whereas those in Germany and Italy already have access to similar regional and supraregional training provision [48].

The main cultural differences lay in the compilation of material for the Teacher Training Tool, which was compiled by a three-country team. We established that in Germany and Italy, it is common in learning situations to address the learner-here, the vocational school teacher-using the second 
person, whereas this is not the preference of Polish teachers. As a result, the Polish-language version of the online tool makes use of indirect forms of address in its learning content.

In relation to the self-study concept of online training with the Teacher Training Tool, the tool increased the skills of Polish teachers to learn independently though e-learning significantly more than was the case with German teachers (M 3.26 and M 2.48 respectively; $p<0.001)$. This perception on the part of the Polish teachers was also reflected in their general acceptance of e-learning and, hence, their motivation and satisfaction. By contrast, we identified a certain scepticism among the Italian teachers, who had a more negative perception overall both of e-learning in general and of the Teacher Training Tool in particular.

\section{Conclusions}

European VET research has so far paid only scant attention to the issue of how vocational school teachers rate and accept the use of a specific online in-service training measure. Our study aims to fill this gap and documents the substantial relevance of e-learning provision to European teacher training. We have concluded that the online learning approach to in-service training for vocational school teachers is of great interest and that those taking advantage of the opportunities saw great benefit to themselves. Although vocational school teachers constituted the target group for this study, it is possible to extend the findings to teachers in other types of institutions with similar framework conditions (such as a shortage of time). From a European perspective, it is important that provision is made for teachers to undergo lifelong learning to guarantee the high quality of vocational education. However, these and the following statements are to be assessed very carefully, since in our study included only three countries with a small number of participants representing each. In order to be able to integrate more general statements about various countries, an expansion of the this would be necessary. At the same time, however, the inclusion of countries with completely different cultures would require a significant adaptation of both the treatment and the survey design [64-66].

The transfer of initial and continuing training provision at the international level supported by online tools offers the opportunity for a supranational concept of in-service training that is nonetheless adapted to specific countries and cultures (see also chapter 6). At the same time, a cross-border model argues for international development teams working on producing high-quality in-service training materials that can be used across a range of cultures. This would enable innovative in-service training provision to be developed in a range of places to allow comparable challenges in teacher training to be tackled. Meanwhile, a supranational online learning tool would encourage a more even distribution of the high development costs for such online in-service training measures and help secure long-term improvements in vocational training across Europe.

The findings clearly show that teachers are generally positively disposed to computer technology and e-learning. The added value of this study lies not only in its evaluation of online learning for vocational school teachers but also in the recognition that online learning can be used as a tool for in-service training specifically designed for vocational school teachers. The findings also show that the quality of learning units is crucial to the acceptance of e-learning provision. The extent to which formal in-service training measures exist for teachers in individual countries is also very significant. Further research in this area will be important in obtaining detailed insights into the needs and impact of online training for vocational school teachers. This is particularly true at the European level, where current studies are focusing on individual in-service training courses or country-specific provision. However, considering the added value of e-learning as an addition to existing provision raises the question of why, from an academic perspective, so little attention has so far been paid to this aspect of on-service training for teachers despite the intensive focus on areas such as digitalisation within schools.

Finally, however, it should be noted that the modelling of this study can take only limited account of the diverse and country-specific cultural aspects and the differing systems of teacher training. These aspects require considerable further comparative international research in the area of in-service teacher training. 
Author Contributions: All contributions are shared by both authors. All authors have read and agreed to the published version of the manuscript.

Funding: The presented findings were made as part of the project "ReCall" (Retail Sector Competencies for all Teachers), funded by the program Erasmus + of the European Union (2015-1-DE02-KA202-002315).

Acknowledgments: Special thanks to the project partners with their teams at the University of Bergamo (Michele Brunelli) and at the Pedagogical University of Kraków (Slawomir Kurek and Tomasz Rachwal) as well as to the participating vocational schools.

Conflicts of Interest: The authors declare no conflict of interest.

\section{References}

1. European Commission. Europe's Digital Progress Report 2017. Available online: https://ec.europa.eu/digitalsingle-market/en/news/europes-digital-progress-report-2017 (accessed on 19 May 2019).

2. Grass, K.; Weber, E. EU 4.0-The Debate on Digitalisation and the Labour Market in Europe (No. 39/2016). IAB Discussion Paper. Available online: http://doku.iab.de/discussionpapers/2016/dp3916_en.pdf (accessed on 9 March 2020).

3. McKinsey Global Institute. Digital Europe: Pushing the Frontier, Capturing the Benefits. Available online: https://www.mckinsey.com/ \{\}/media/McKinsey/Business\%20Functions/McKinsey\%20Digital/Our\% 20Insights/Digital\%20Europe\%20Pushing\%20the\%20frontier\%20capturing\%20the\%20benefits/DigitalEurope-Full-report-June-2016.ashx (accessed on 9 March 2020).

4. OECD. The Organization for Economic Cooperation and Development. In OECD Skills Outlook 2019: Thriving in a Digital World; OECD Publishing: Paris, France, 2019.

5. Cedefop. The Great Divide: Digitalisation and Digital Skill Gaps in the EU Workforce. Thessaloniki, Greece, 2016. Available online: http://www.cedefop.europa.eu/files/esj_insight_9_digital_skills_final.pdf (accessed on 9 March 2020).

6. UK NARIC. Key Competences in Vocational Education and Training-United Kingdom (Cedefop ReferNet Thematic Perspectives Series). Available online: http://libserver.cedefop.europa.eu/vetelib/2016/ReferNet_ UK_KC.pdf (accessed on 19 May 2019).

7. Chien, J. How digital media and Internet transforming education. In Proceedings of the AACE, E-Learning Conference, Montréal, QC, Canada, 01 November 2012. Available online: https://www.researchgate.net/profile/Jemmy_Chien/publication/235901330_How_digital_media_and_ Internet_transforming_education/links/0912f513f7665201d8000000/How-digital-media-and-Internettransforming-education.pdf?origin=publication_detail (accessed on 12 March 2020).

8. Higgins, S.; Xiao, Z.; Katsipataki, M. The Impact of Digital Technology on Learning: A Summary for the Education Endowment Foundation; Durham University: Durham, UK, 2012. Available online: https://pdfs. semanticscholar.org/d26b/b59f2536107b57f242b8289b1eb6f51d8765.pdf (accessed on 9 March 2020).

9. Granito, M.; Chernobilsky, E. The Effect of Technology on a Student's Motivation and Knowledge Retention. In Proceedings of the NERA Conference, Rocky Hill, CT, USA, 17-19 October 2012; Available online: https://www.nera-education.org/docs/NERA_Conference_Program_2012.pdf (accessed on 9 March 2020).

10. Glushkova, T. Adaptive Model for E-Learning in Secondary School. In E-Learning-Long-Distance and Lifelong Perspectives; Pontes, E., Silva, A., Guelfi, A., Kofuji, S.T., Eds.; InTech: Rijeka, Croatia, 2012; pp. 3-22. ISBN 978-953-51-0250-2. [CrossRef]

11. Harvey, D.; Greer, D.; Basham, J.; Hu, B. From the Student Perspective: Experiences of Middle and High School Students in Online Learning. Am. J. Distance Educ. 2014, 28, 14-26. [CrossRef]

12. Liu, M.; Toprac, P.; Yuen, T.T. What Factors Make a Multimedia Learning Environment Engaging. In Cognitive Effects of Multimedia Learning; Zheng, R., Ed.; IGI Global: Hershey, PA, USA, 2009; pp. 173-192.

13. Morgan, H. Online Instruction and Virtual Schools for Middle and High School Students: Twenty-First-Century Fads or Progressive Teaching Methods for Today's Pupils? Clear. House J. Educ. Strateg. Issues Ideas 2015, 88, 72-76. [CrossRef]

14. Nicholas, H.; Ng, W. Engaging Secondary School Students in Extended and Open Learning Supported by Online Technologies. J. Res. Technol. Educ. 2009, 41, 305-328. [CrossRef]

15. Zwart, D.P.; van Luit, J.E.H.; Noroozi, O.; Goei, S.L.; Cheng, M. The effects of digital learning material on students' mathematics learning in vocational education. Cogent Educ. 2017, 4, 632. [CrossRef] 
16. Redecker, C.; Punie, Y. European Framework for the Digital Competence of Educators: DigCompEdu; Publications Office of the European Union: Luxembourg, 2017; ISBN 978-92-79-73494-6.

17. Cairncross, S.; Mannion, M. Interactive Multimedia and Learning: Realizing the Benefits. Innov. Educ. Teach. Int. 2001, 38, 156-164. [CrossRef]

18. Harper, B.; Hedberg, J.; Bennett, S.; Lockyer, L. Review of Research. The on-Line Experience (The state of Australian on-Line Education and Training Practices); NCVER: Kensington Park, SA, Australia, 2000; ISBN 0-87397-639-8.

19. Mayer, R.E. (Ed.) The Cambridge Handbook of Multimedia Learning, 2nd ed.; Cambridge University Press: New York, NY, USA, 2014; ISBN 978-1-107-03520-1. [CrossRef]

20. Welsh, E.T.; Wanberg, C.R.; Brown, K.G.; Simmering, M.J. E-learning. Emerging uses, empirical results and future directions. Int. J. Train. Dev. 2003, 7, 245-258. [CrossRef]

21. Cedefop. Professional Development for VET Teachers and Trainers: A Guarantee of Quality in Vocational Education and Training (Briefing Note, April 2016). Available online: https://www.cedefop.europa.eu/files/ 9112_en.pdf (accessed on 6 April 2020).

22. Scheerens, J. Teachers' Professional Development: Europe in International Comparison; an Analysis of Teachers' Professional Development Based on the OECD's Teaching and Learning International Survey, (TALIS); Scheerens, J., Ed.; Office for Official Publications of the European Union: Luxembourg, 2010; ISBN 978-92-79-15186-6. [CrossRef]

23. Desurmont, A.; Forsthuber, B.; Oberheidt, S. Levels of Autonomy and Responsibilities of Teachers in Europe; Eurydice: Brussels, Belgium, 2008; ISBN 978-92-79-08898-8. [CrossRef]

24. Siemens, G.; Gašević, D.; Dawson, S. Preparing for the Digital University: A Review of the History and Current State of Distance, Blended, and Online Learning; Athabasca University: Athabasca, AB, Canada, 2015.

25. Yuen, A.H.; Ma, W.W. Exploring teacher acceptance of e-learning technology. Asia-Pac. J. Teach. Educ. 2008, 36, 229-243. [CrossRef]

26. Salloum, S.A.; Al-Emran, M.; Shaalan, K.; Tarhini, A. Factors affecting the E-learning acceptance: A case study from UAE. Educ. Inf. Technol. 2019, 24, 509-530. [CrossRef]

27. Moore, J.; Dickson-Deane, C.; Galyen, K.; Chen, W. Designing for E-learn, Online, and Distance Learning Environments: Are They the Same? 2010. Available online: https://www.researchgate.net/publication/ 233751524 (accessed on 3 June 2020).

28. Markova, T.; Glazkova, I.; Zaborova, E. Quality Issues of Online Distance Learning. Procedia Soc. Behav. Sci. 2017, 237, 685-691. [CrossRef]

29. Loogma, K.; Kruusvall, J.; Ümarik, M. E-learning as innovation: Exploring innovativeness of the VET teachers' community in Estonia. Comput. Educ. 2012, 58, 808-817. [CrossRef]

30. Kalmus, V.; Pruulmann-Vengerfeldt, P.; Runnel, P.; Siibak, A. Mapping the Terrain of "Generation C": Places and Practices of Online Content Creation Among Estonian Teenagers. J. Comput. Mediat. Commun. 2009, 14, 1257-1282. [CrossRef]

31. Eurostat. Individuals-Frequency of Internet Use, 16 to 19 Years Old. Available online: https://appsso. eurostat.ec.europe.eu/nui/show.do?dataset=isoc_ci_ifp_fu\&lang=en (accessed on 25 May 2020).

32. Koohang, A.A. A Study of Attitudes Toward Computers. J. Res. Comput. Educ. 1989, 22, 137-150. [CrossRef]

33. Violato, C.; Marini, A.; Hunter, W.A. Confirmatory Factor Analysis of a Four-Factor Model of Attitudes Toward Computers. J. Res. Comput. Educ. 1989, 22, 199-213. [CrossRef]

34. Ernest, P.; Guitert Catasús, M.; Hampel, R.; Heiser, S.; Hopkins, J.; Murphy, L.; Stickler, U. Online teacher development: Collaborating in a virtual learning environment. Comput. Assist. Lang. Learn. 2013, 26, 311-333. [CrossRef]

35. Behera, S.K. E-Learning in Teacher Education. Pedagog. Learn. 2013, 1, 17-22.

36. Jung, I. ICT-Pedagogy Integration in Teacher Training: Application Cases Worldwide. J. Educ. Technol. Soc. 2005, 8, 94-101.

37. Robinson, B.; Latchem, C. Teacher education: Challenge and change. In Teacher Education through Open and Distance Learning; Robinson, B., Latchem, C., Eds.; Routledge: London, UK, 2003; pp. 1-27. ISBN 0-415-36956-8.

38. Carlson, S.; Gadio, C.T. Teacher professional Development in the Use of Technology. In Technologies for Education: Potentials, Parameters, and Prospects; Haddad, W.D., Draxler, A., Eds.; Unesco and AED: Paris, France, 2002; pp. 118-132. ISBN 0-89492-112-6.

39. Davis, F.D. Perceived Usefulness, Perceived Ease of Use, and User Acceptance of Information Technology. MIS Q. 1989, 13, 319. [CrossRef] 
40. Goodhue, D.L. Understanding User Evaluations of Information Systems. Manag. Sci. 1995, 41, 1827-1844. [CrossRef]

41. Mandl, H.; Burg, O. Acceptance of e-learning at the workplace: The influence of institutional framework. In The Learning Potential of the Workplace; Nijhof, W.J., Ed.; Sense Publishers: Rotterdam, The Netherlands, 2008; pp. 213-224. ISBN 978-90-8790-372-5. [CrossRef]

42. El Mouldi, S.; Mouelhi, N.B.D. Irritating Factors While Navigating on Websites and Facebook and Its Reactions Using Different Devices. In Mobile Platforms, Design, and Apps for Social Commerce; Pelet, J.-É., Ed.; IGI Global: Hershey, PA, USA, 2017; pp. 135-152. ISBN 9781522524700.

43. Lipowsky, F. Unterrichtsentwicklung durch Fort- und Weiterbildungsmassnahmen für Lehrpersonen. Beiträge zur Lehrerinnen-und Lehrerbildung 2009, 27, 346-360.

44. Ehlers, U.-D. Quality in E-Learning from a Learner's Perspective. Eur. J. Opendistance E-Learn. 2004, 7, 1-8. [CrossRef]

45. Wixom, B.H.; Todd, P.A. A Theoretical Integration of User Satisfaction and Technology Acceptance. Inf. Syst. Res. 2005, 16, 85-102. [CrossRef]

46. Butcher, K.R. The Multimedia Principle. In The Cambridge Handbook of Multimedia Learning; Mayer, R., Ed.; Cambridge University Press: Cambridge, UK, 2014; pp. 174-205. ISBN 978-1-107-03520-1.

47. Harrati, N.; Bouchrika, I.; Mahfouf, Z.; Ladjailia, A. Evaluation Methods for E-Learning Applications in Terms of User Satisfaction and Interface Usability. In Handbook of Research on Innovative Pedagogies and Technologies for Online Learning in Higher Education; Vu, P., Frederickson, S., Moore, C., Eds.; IGI Global: Hershey, PA, USA, 2017; pp. 427-448. ISBN 9781522518525.

48. Cedefop. Vocational Education and Training in Italy: Short Description; Publications Office of the European Union: Luxembourg, 2014; ISBN 978-92-896-1656-0. [CrossRef]

49. Chłoń-Domińczak, A.; Dębowski, H.; Holzer-Żelażewska, D.; Maliszewska, A. Vocational Education and Training in Europe-Poland. Cedefop ReferNet VET in Europe Reports. 2016. Available online: https: //cumulus.cedefop.europa.eu/files/vetelib/2016/2016_CR_PL.pdf (accessed on 6 April 2020).

50. Fürstenau, B.; Pilz, M.; Gonon, P. The Dual System of Vocational Education and Training in Germany-What Can Be Learnt About Education for (Other) Professions. In International Handbook of Research in Professional and Practice-based Learning; Billett, S., Harteis, C., Gruber, H., Eds.; Springer: Dordrecht, The Netherlands, 2014; pp. 427-460. ISBN 978-94-017-8902-8.

51. Bailey, K.D. Methods of Social Research, 4th ed.; Free Press: New York, NY, USA, 1994; ISBN 978-1-4165-7694-5.

52. Bhattacherjee, A. Social Science Research: Principles, Methods, and Practices, 2nd ed.; University of South Florida: Tampa, FL, USA, 2012; ISBN 978-1475146127.

53. Banville, D.; Desrosiers, P.; Genet-Volet, Y. Translating Questionnaires and Inventories Using a Cross-Cultural Translation Technique. J. Teach. Phys. Educ. 2000, 19, 374-387. [CrossRef]

54. Brislin, R.W. Back-Translation for Cross-Cultural Research. J. Cross-Cult. Psychol. 1970, 1, 185-216. [CrossRef]

55. Edeling, S.; Pilz, M. Teaching self- and social competencies in the retail sector: Findings from vocational schools in Germany, Italy and Poland. Educ. Train. 2016, 58, 1041-1059. [CrossRef]

56. Flick, U. An Introduction to Qualitative Research, 5th ed.; Sage: Los Angeles, CA, USA, 2014; ISBN 978-1-4462-6778-3.

57. Leung, S.O. A comparison of psychometric properties and normality in 4-, 5-, 6-, and 11-point Likert scales. J. Soc. Serv. Res. 2011, 37, 412-421. [CrossRef]

58. Wu, H.; Leung, S.O. Can Likert Scales be Treated as Interval Scales?-A Simulation Study. J. Soc. Serv. Res. 2017, 43, 527-532. [CrossRef]

59. Fagan, M.H.; Stern, N.; Wooldrige, B.R. Exploring the Intention to Use Computers: An Empirical Investigation of the Role of Intrinsic Motivation, Extrinsic Motivation, and Perceived Ease of Use. J. Comput. Inf. Syst. 2008, 48, 31-37.

60. Nikou, S.A.; Economides, A.A. Mobile-Based Assessment: Integrating acceptance and motivational factors into a combined model of Self-Determination Theory and Technology Acceptance. Comput. Hum. Behav. 2017, 68, 83-95. [CrossRef]

61. Moore, D.S.; McCabe, G.P.; Craig, B.A. Introduction to the Practice of Statistics [with Unique International Edition Exercises], 7th ed.; Freeman: New York, NY, USA, 2012; ISBN 978-1-4292-8664-0. 
62. Siekiera, A.; Luck, A. Supporting teachers and trainers for successful reforms and quality of vocational education and training: Mapping their professional development in the EU-Poland. Cedefop Ref. Themat. Perspect. Ser. 2018. Available online: https://cumulus.cedefop.europa.eu/files/vetelib/2016/ReferNet_PL_TT. pdf (accessed on 13 June 2019).

63. Hogeforster, M. Education Policy Strategies Today and Tomorrow around the "Mare Balticum", 1st ed.; Baltic Sea Academy: Hamburg, Germany, 2011; ISBN 9783842374218.

64. Keller, A.; Zirkle, C.; Barabasch, A. Focal points of VET teacher training: A comparison of VET teacher education in the USA and Switzerland. Comp. J. Comp. Int. Educ. 2019, 1-19. [CrossRef]

65. Harris, R. Reflections on VET teacher education in Australia, against the backdrop of VET teacher education in Germany. In Konzepte und Wirkungen des Transfers Dualer Berufsausbildung; Gessler, M., Fuchs, M., Pilz, M., Eds.; Springer VS: Wiesbaden, Germany, 2019; pp. 347-363. ISBN 978-3-658-23184-2.

66. Pilz, M.; Gengaiah, U. Teacher Training Education for VET Teachers in India. In Handbook of Vocational Education and Training; McGrath, S., Mulder, M., Papier, J., Suart, R., Eds.; Springer: Cham, Germany, 2019; pp. 1733-1746.

(C) 2020 by the authors. Licensee MDPI, Basel, Switzerland. This article is an open access article distributed under the terms and conditions of the Creative Commons Attribution (CC BY) license (http://creativecommons.org/licenses/by/4.0/). 